\title{
ЦЕЛЕВОЕ ПРЕДНАЗНАЧЕНИЕ НОРМ-ИЗЪЯТИЙ
}

\author{
(C) 2021 Бордакова Анна Геннадьевна \\ старший преподаватель, кафедра теории права и философии \\ Самарский государственный экономический университет, Россия, Самара \\ E-mail: ansan12263@mail.ru
}

В статье анализируются цели норм-изъятий, среди которых автор выделят конкретизацию содержания особых юридических предписаний, выполнение международных, государственных и общественных функций, обеспечение юридической безопасности и др. Отмечается, что при этом нормы-изъятия должны соответствовать принципам справедливости, равенства и гуманизма.

Ключевые слова: цели, нормы-изъятия, конкретизация, охрана, согласование интересов, юридическая безопасность, дифференциация регулирования.

Право, как социальный феномен, содержит значительное количество специальных установлений, посредством которых достигается регулятивное воздействие на конкретные виды общественных отношений. Нормы-изъятия, имеющие место в правовой регламентации социальных связей, характеризуются тем, что позволяют отступать от общеустановленных правил поведения, закрепленных в юридических предписаниях. Данные специальные установления содержатся во многих нормативных правовых актах. Однако в юридической науке вопросам целевого предназначения норм-изъятий уделяется весьма незначительное внимание. В связи с чем правовой анализ целей норм-изъятий в общетеоретическом плане представляет несомненный интерес.

В философии под целью понимается предвосхищенный результат, на достижение которого направлены действия определенных субъектов [9, с.459]. В юриспруденции цель есть то, к чему нужно стремиться, что необходимо реализовать [7, с.416].

Установление и обеспечение государством целей специально-правового регулирования особых общественных отношений обеспечивает устойчивое и прочное бесперебойное функционирование специфических социальных связей. Напротив, отсутствие этих целей, либо осуществление какой-либо деятельности вопреки или вразрез с этими целями, неминуемо приводит к негативным последствиям.

По справедливому замечанию С.Ю.Суменкова, исследовавшего цели исключений в праве как особой формы норм-изъятий, «Цель в той мере, в какой она верно отражает существую- щую реальность и определяет направления и пути её преобразования, свидетельствует об объективной природе исключений, указывает на их соответствие потребностям общественного развития, интересам государства, социальных групп, отдельной личности» [8, с. 80].

Правильное определение целей норм-изъятий, безусловно, влияет на процессы правотворчества и правоприменения, их совершенствование, формирование и повышение уровня правосознания и правовой культуры общества. Именно цели имеют первостепенное значение при характеристике норм-изъятий. Цель норм-изъятий определяет основные направления преобразования правовой действительности, демонстрирует особую природу норм-изъятий, указывает на их соответствие социально значимым ценностям.

Цели, стоящие перед нормами-изъятиями, носят многоплановый характер. Нормы-изъятия, будучи юридическими средствами особого правового регулирования, преследуют с иными средствами упорядочивания общественных отношений общие цели права: формирование правового государства и гражданского общества, обеспечение и защиту законных интересов субъектов права и т.д. В тоже время перед нормами-изъятиями стоят более конкретные цели, обусловленные спецификой специальных установлений. Так, в одних случаях посредством норм-изъятий осуществляется конкретизация общественных отношений.

Анализ литературы, посвященной изучению данного вопроса, показал, что несмотря на многообразие позиций к определению понятия «конкретизация», в целом высказанные точки 
зрения объединяет понимание конкретизации как повышение уровня определенности содержания правовых норм. Так, В. М. Баранов рассматривает конкретизацию как дифференциацию юридических предписаний, которая совершенствует содержание и форму абстрактной нормы права посредством детализации содержания до некой степени определенности [1, с.52-63]. Н.А.Власенко считает, что конкретизация как свойство правового регулирования заключается в переводе неопределенности правовой нормы в ее определенность [2, с. 57-62]. Однако Н.А. Власенко полагает более уместным говорить о конкретности как определенном качестве, свойстве, но не о конкретизации. Конкретизация, по его мнению, это процесс приобретения юридическим предписанием свойства конкретности, определенности.

Посредством конкретизации происходит определение и уточнение специфических, нестандартных видов социальных связей, в корне отличающихся от общих правовых установлений. Соответственно в целях уточнения и определенности нормы-изъятия фиксируют круг участников конкретных специфических отношений, уточняют их права и обязанности, устанавливают меры юридической ответственности за нарушение норм и требований и т.д.

В частности, лица, заключившие трудовой договор на срок до 2 месяцев, и лица, занятые на сезонных работах, имеют отличные правила расторжения трудового договора по сравнению со всеми остальными работниками. Если все работники вправе расторгнуть трудовое соглашение, предупредив об этом работодателя за 2 недели, то для вышеуказанной категории работников установлено правило, согласно которому они должны предупредить своего работодателя за 3 календарных дня. В свою очередь, работодатель при ликвидации организации, сокращении численности или штата работников должен сообщить о предстоящем увольнении не за 2 месяца, как это было бы в отношении всех иных работников, а за 3 календарных дня, а в случае с сезонными работниками - за 7 календарных дней (ст. 292, 296 ТК РФ) [10].

При этом при конкретизации возможны как расширение содержания юридической нормыизъятия, так и уменьшение ее объема. К примеру, статьей 2 Закона РФ от 21.07.1993 г. № 5485-1 «O государственной тайне» [4] закрепляются основные понятия, используемые в названном нормативном правовом акте, среди которых, прежде всего, указана дефиниция «перечень сведений, составляющих государственную тайну». Ее содержание уточнено в ст. 5 указанного правового документа. Однако, определяя содержание сведений в области внешней политики и экономики, составляющих государственную тайну, законодатель в некоторых ситуациях уменьшает их объем. В частности, согласно абз. 2 п. 3 ст. 5 Закона «О государственной тайне» государственную тайну составляют сведения о финансовой политике в отношении иностранных государств (за исключением, обобщенных показателей по внешней задолженности). Напротив, в данном нормативном правовом акте, но уже в абз. 4 ст. 12, законодатель использует расширение содержания нормативного предписания, когда определяет реквизиты носителей сведений, составляющих государственную тайну. А именно, закрепляется, что на носителе или сопроводительной документации к нему могут проставляться дополнительные отметки, определяющие полномочия должностных лиц по ознакомлению с содержащимися в этом носителе сведениями.

В связи с чем можно сделать вывод о том, что по отношению к нормам-изъятиям конкретизация выражается в уточняющем характере последней. Вместе с тем далеко не все нормыизъятия обладают конкретизирующим свойством. Ввиду многообразия норм-изъятий некоторые упомянутые специальные предписания не конкретны, а, наоборот, абстрактны. Иными словами, данная цель правового регулирования свойственна не всем нормам-изъятиям.

Однако любая норма-изъятие направлена на обеспечение законных интересов личности, общества и государства. Следовательно, в системе правового регулирования нормы-изъятия позволяют «удержать» те или иные общественные отношения в правовом пространстве. В противном случае, несвоевременное воздействие названных специальных юридических установлений может привести к определенному правовому вакууму, способному породить многочисленные негативные последствия.

Вместе с тем нормы-изъятия по своим свойствам не охватывают все существующие в обществе интересы и потребности. Специальные правовые установления воздействуют лишь на определенный круг общественных связей, обладающих некой спецификой. Нормы-изъятия в 
одних случаях могут быть направлены на охрану самого физического бытия личности, в других, обеспечение выполнение международных, государственных и общественных функций, служебных официальных обязанностей определенных категорий должностных лиц и т.д.

В связи с чем, можно прийти к выводу о том, что нормы-изъятия направлены на согласование разнообразных, неоднородных по содержанию, интересов. Тем самым данные специальные правовые установления позволяют достигнуть определенного консенсуса, баланса интересов различных членов общества в социальных условиях, отличных от обычных.

Так, целью установления правового иммунитета выступает предоставление повышенной правовой защиты должностным лицам, которые выполняют государственно значимую функцию либо лицом, осуществляющим от имени государства международную деятельность. Согласно ст. 19 Генерального соглашения о привилегиях и иммунитетах Совета Европы привилегии и иммунитеты предоставляются должностным лицам не для их личной выгоды, а в интересах Coвета Европы [3]. Должностные лица, наделенные правовым иммунитетом, не подлежат аресту, заключению под стражу и др. формам ограничения свободы человека. Вместе с тем иммунитет не имеет абсолютного характера и не может выступать в роли своеобразной «индульгенции» от различных проступков, в т.ч. противоправного характера. Правовой иммунитет имеет строго оговоренные законом границы и в ряде случаев может быть отменен и ограничен. Поэтому правовой иммунитет, предоставляя правовую защиту определенным должностным лицам от мер правового принуждения имеет своей целью гарантирование беспрепятственного осуществления данными субъектами своих специфических служебных функций в обществе и государстве. Обладание правовым иммунитетом отдельными категориями должностных лиц не улучшает их правовое положение по сравнению с другими субъектами. Напротив, если не будет соблюден ряд особенностей предоставления правовой защиты таким участникам правовых отношений, то выполнение ими ряда служебных функций становится весьма проблематичным.

Вместе с тем в юридической практике встречаются случаи злоупотребления правовыми иммунитетами. В настоящее время российское общество пронизано такими опасными соци- альными явлениями как коррупция, бюрократизм, организованная преступность. Сегодня в России очень большое количество должностных лиц, которые ограждены от судебного преследования, в т.ч. за коррупцию, их невозможно задержать (кроме как с поличным), арестовать или обыскать. В этом плане иммунитет депутата, члена Совета Федерации и судьи аналогичен иммунитету президента. К тому же вышеперечисленные категории подлежат особому порядку уголовного преследования с необходимостью получения множества санкций на следственные действия, что, безусловно, мешает оперативно вести уголовное или административное расследование. Поэтому в России количество вынесенных обвинительных приговоров в отношении вышеназванных субъектов весьма невелико, что связано с «чрезмерным» иммунитетом.

В рамках рассмотрения целевого предназначения норм-изъятий следует отметить, что некоторые специальные установления, содержащиеся в национальном законодательстве, нацелены на обеспечение юридической безопасности субъектов права.

Безопасность выступает универсальной ценностью, к которой стремится право. Право направлено на обеспечение защищенности и сохранности основных социальных интересов общества, гарантирование определенной стабильности в обществе и его устойчивое развитие. Цель обеспечения безопасности позволяет удержать определенные общественные отношения в неких рамках. На наш взгляд, цель обеспечения безопасности наиболее ярко находит свое воплощение именно в нормах-изъятиях.

Не вдаваясь в дискуссию о понятии безопасности и ее видах, отметим, что зачастую юридическая безопасность как вид безопасности представляет собой совокупность осуществляемых в правовой системе и посредством права способов и мер правовой охраны и защиты [12, с. 10]. Нормы-изъятия тем самым способствуют предотвращению наступлению неблагоприятных последствий либо направлены на скорейшую их ликвидацию. Так, из смысла ст. 3.12 КоАП РФ [6] можно сделать вывод о том, что административное приостановление деятельности назначается в случаях угрозы жизни и здоровью людей, возникновения эпизоотий и эпидемий, наступления радиационной аварии или техногенной катастрофы и т.д. при условии, что менее строгий вид административного наказания не сможет 
обеспечить достижение цели административного наказания.

Нередко нормы-изъятия служат неким правовым барьером для достижения противоправной цели. Так, согласно подп. 5 ч. 3 ст. 11 Федерального закона от 6 марта 2006 г. № 35-Ф3 «О противодействии терроризму» [11] на территории, в пределах которой введен правовой режим контртеррористической операции, на период ее проведения могут использоваться транспортные средства, принадлежащие организациям независимо от форм собственности (за исключением транспортных средств дипломатических представительств, консульских и иных учреждений иностранных государств и международных организаций), а в неотложных случаях и транспортные средства, принадлежащие физическим лицам, для доставления лиц, нуждающихся в срочной медицинской помощи, в лечебные учреждения, а также для преследования лиц, подозреваемых в совершении террористического акта, если промедление может создать реальную угрозу жизни или здоровью людей.

Исходя из изложенного, можно прийти к выводу о том, что нормы-изъятия способствуют дифференциации правового регулирования, что приводит к его эффективности и полноте. В то же время нормы-изъятия формируют условия для благотворной жизнедеятельности различных субъектов, обеспечивая достижение между их интересами и потребностями некоего компромисса, баланса.

Вместе с тем полной гармонии можно до- стичь, если нормы-изъятия будут соответствовать принципам справедливости, равенства и гуманизма. Нормы-изъятия не нарушают принципы справедливости и равенства. Выступая общезначимой ценностью, нравственнообоснованным критерием, справедливость соизмеряет общественные явления и действия субъектов с позиции добра и зла, равенства и неравенства [5, с.108].

Некоторые специальные правовые установления буквально пронизаны гуманитарным характером. Именно принцип гуманизма является одним из факторов появления норм-изъятий в уголовном и административном законодательстве, что связано с необходимостью предоставления особой защиты прав некоторым категориям субъектов при привлечении последних к соответствующему виду юридической ответственности. Так, административный арест не может быть назначен беременным женщинам, женщинам, имеющим малолетних детей, несовершеннолетним, инвалидам 1 и 2 групп и др. (ч. 2 ст. 3.9 КоАП РФ) [6]. Однако принцип гуманизма не следует абсолютизировать, в противном случае, правовое воздействие может оказаться неэффективным и нецелесообразным.

Подводя итог вышесказанному, еще раз подчеркнем, что цели, стоящие перед нормамиизъятиями, многоаспектны. Установление государством целей специального правового регулирования особых общественных отношений обеспечивает устойчивое и прочное функционирование специфических социальных связей.

\section{Библиографический список}

1. Баранов В.М. Негативные аспекты конкретизации юридических норм // Конкретизация права: теоретические и практические проблемы: материалы IX Международной научно-практической конференции. М.: РГУП, 2015. С. 52-63.

2. Власенко Н.А. Конкретизация в праве: природа и пути исследования // Конкретизация законодательства как технико-юридический прием нормотворческой интерпретационной правоприменительной практики: материалы Международного симпозиума (Геленджик, 27-28 сентября 2007 г.) / под ред. В. М. Баранова. Н. Новгород: Нижегородская академия МВД России, 2008. С. 57-62.

3. Генеральное соглашение о привилегиях и иммунитетах Совета Европы (БТ8 № 2) с Присоединениями к данному Соглашению (заключено в г. Париже 2 сентября 1949 г.) // Бюллетень международных договоров. 1997. № 5. С. 27-32.

4. Закон РФ от 21 июля 1993 г. № 5485-1 «О государственной тайне» (в ред. от 30.12.2020) // Российская газета. 1993. 21 сент.

5. Катомина В.А. Концепция справедливости в условиях развития российского общества // Философия права. 2009. № 6. С. 108-111.

6. Кодекс Российской Федерации об административных правонарушениях от 30 декабря 2001 г. № $195-Ф 3$ (в ред. от 30.12.2020) // Собрание законодательства РФ. 2002. № 1 (ч. 1). Ст. 1. 
7. Общая теория государства и права: академический курс в 3-х томах / отв. ред. М.Н. Марченко. 3-е изд., перераб. и доп. Т. 3: Государство, право, общество. М.: НОРМА, 2007. 698 с.

8. Суменков С. Ю. Юридические исключения и их цели: теоретический и практический аспекты // Проблемы теории права: личность, общество, государство: сборник научных статей. Красноярск, 2011. С. $79-85$.

9. Философская энциклопедия. В 5 т. / Глав. ред. Ф. В. Константинов. Т. 5. М.: Сов. энциклопедия, 1970.740 с.

10. Трудовой кодекс Российской Федерации от 30 декабря 2001 г. № 197-ФЗ (в ред. от 29.12.2020) // Собрание законодательства РФ. 2002. № 1 (часть I). Ст. 3.

11. Федеральный закон от 6 марта 2006 г. № 35-ФЗ «О противодействии терроризму» (в ред. от 08.12.2020) // Собрание законодательства РФ. 2006. № 11. Ст. 1146.

12. Фомин А.А. Юридическая безопасность субъектов российского права (вопросы теории и практики): автореф. дис. ... док. юрид. наук. Саратов, 2008. 58 с. 